Tersedia online di: http://ejournal-balitbang.kkp.go.id/index.php/jra

\title{
PEMBENTUKAN POPULASI SINTETIS UNTUK PENINGKATAN KUALITAS GENETIK IKAN MAS
}

\section{Didik Ariyanto*\#, Odang Carman ${ }^{* *}$, Dinar Tri Soelistyowati**), Muhammad Zairin Junior ${ }^{* *}$, M. Syukur $^{* * *}$, Yogi Himawan*), dan Flandrianto S. Palimirmo*)}

\author{
*) Balai Riset Pemuliaan Ikan \\ Jl. Raya 2 Sukamandi, Subang 41263, Jawa Barat \\ *) Departemen Budidaya Perairan, Fakultas Perikanan dan Ilmu Kelautan, Institut Pertanian Bogor \\ Kampus IPB Darmaga, Jalan Agatis, Babakan, Kec. Dramaga, Kota Bogor, Jawa Barat 16128 \\ ***) Departemen Agronomi dan Hortikultura, Fakultas Pertanian, Institut Pertanian Bogor \\ Institut Pertanian Bogor, Kampus, Jl. Meranti, Babakan, Kec. Dramaga, Bogor, Jawa Barat 16680
}

(Naskah diterima: 23 April 2021; Revisi final: 11 Mei 2021; Disetujui publikasi: 11 Mei 2021)

\begin{abstract}
ABSTRAK
Benih ikan mas telah mengalami penurunan kualitas genetik yang menyebabkan penurunan performa fenotipik di lingkungan budidaya. Salah satu upaya perbaikan genetik adalah melalui pembentukan populasi sintetis yang merupakan penggabungan potensi genetik beberapa populasi plasma nutfah ikan mas. Penelitian ini bertujuan membentuk dan mengevaluasi performa genotipik dan fenotipik populasi sintetis ikan mas, yang merupakan penggabungan dari strain Rajadanu, Majalaya, Sutisna, Wildan, dan Sinyonya. Performa genotipik dievaluasi menggunakan metode mikrosatelit DNA, sedangkan performa fenotipik dievaluasi menggunakan analisis biometrik terkait kegiatan budidaya. Hasil penelitian menunjukkan bahwa nilai keragaman genetik populasi sintetis lebih tinggi 55,0\%287,5\% dengan tingkat inbreeding 40,0\% 77,14\% lebih rendah dibanding populasi-populasi pembentuknya. Hal ini berdampak terhadap performa fenotipik populasi sintetis yang lebih baik, diindikasikan dengan peningkatan panjang, bobot akhir, dan tingkat produktivitas, masing-masing sebesar 2,5\%20,6\% 9,4\%61,8\% dan 18,2\%66,0\%lebih baik dibanding populasi-populasi pembentuknya. Peningkatan kualitas genetik dan performa fenotipik populasi sintetis ini memberikan peluang untuk memperbaiki kualitas benih ikan mas pada kegiatan budidaya.
\end{abstract}

KATAKUNCl: ikan mas; populasi sintetis; genotipik; fenotipik

ABSTRACT: Forming synthetic populations for genetic improvement of common carp. By: Didik Ariyanto, Odang Carman, Dinar Tri Soelistyowati, Muhammad Zairin Junior, Muhamad Syukur, Yogi Himawan, dan Flandrianto S. Palimirmo

Common carp in Indonesia has experienced a decline in genetic quality. The progressive decline leads to a significant decrease in carp performance in the farming environment. One of the efforts to genetically improve carp growth performance is through developing synthetic carp populations, which is a blend of the genetic potentials from several germplasm populations. This study aimed to form and evaluate the performance of genotypic and phenotypic of synthetic populations of common carp, blended from five strains of common carp, i.e., Rajadanu, Majalaya, Sutisna, Wildan, and Sinyonya. The genotypic performance was evaluated using the DNA microsatellite method. The phenotypic performance was assessed using biometric analysis, especially in terms of culture performance. The results showed that the genotypic performance of the synthetic populations of common carp was better than that of the founder strains. This performance was indicated by higher genetic diversity values, about $55.0 \% 287.5 \%$ and lower levels of inbreeding, about $40.0 \% 77.1 \%$ compared with their founder populations. Phenotypic performance of the synthetic populations is also better than their founder populations, indicated by higher body length, weight, and productivity, about 2.5\%20.6\% 9.4\%61.8\% and $18.2 \% 66.0 \%$ respectively. The improvement on genetic quality and phenotypic performance of the synthetic population provide opportunities to improve the quality of common carp fry in aquaculture activity.

\section{KEYWORDS: common carp; genotypic; phenotypic; synthetic population}

\footnotetext{
\# Korespondensi: Balai Riset Pemuliaan Ikan

JI. Raya 2 Sukamandi, Subang 41263, Jawa Barat, Indonesia

E-mail: didik_ski@yahoo.com
} 


\section{PENDAHULUAN}

Sistem perbenihan ikan mas (Cyprinus carpio) di Indonesia didominasi oleh pembenih skala kecil. Karakteristik pembenih skala kecil antara lain kepemilikan jumlah induk sedikit, produksi benih relatif terbatas dan pembentukan induk baru menggunakan benih-benih yang berkerabat relatif dekat. Kondisi tersebut diduga mengakibatkan tingginya tingkat silang dalam (inbreeding) pada populasi benih yang dihasilkan (Ariyanto et al., 2018a).

Secara genetik, tingginya tingkat silang dalam pada suatu populasi dapat mengakibatkan terjadinya penghanyutan genetik (genetic drift), penurunan keragaman genetik dan peningkatan homozigositas sehingga terjadi kerentanan genetik (genetic vulnerable) (Xu et al., 2012). Kerentanan genetik ini berdampak terhadap penurunan keragaan fenotipik populasi, terutama pada karakter-karakter ekonomis penting seperti penurunan laju pertumbuhan dan ketahanan terhadap penyakit maupun toleransi terhadap perubahan lingkungan (Gjedrem $\&$ Robinson, 2014). Tingginya tingkat inbreeding dan rendahnya nilai keragaman genetik strain-strain ikan mas di Indonesia sudah dilaporkan oleh Ariyanto et al. (2019a).

Dalam rangka meningkatkan nilai keragaman genetik suatu populasi, salah satu cara yang dapat ditempuh adalah dengan pembentukan populasi sintetis. Fjalestad (2005) menjelaskan bahwa populasi sintetis merupakan penggabungan (blending) plasma nutfah dari beberapa populasi sehingga mempunyai tingkat keragaman genetik lebih tinggi dibanding masing-masing populasi pembentuknya. Pembentukan populasi sintetis telah banyak dilakukan antara lain pada ikan nila (Ninh et al., 2014), ikan salmon (Ødegård et al., 2014), dan ikan gurami (Sutthakiet et al., 2019).

Penelitian ini bertujuan mengevaluasi performa genotipik dan fenotipik khususnya pada karakter pertumbuhan populasi sintetis ikan mas. Hasil penelitian ini akan dijadikan dasar pertimbangan pada kegiatan pemuliaan ikan mas selanjutnya.

\section{BAHAN DAN METODE}

\section{Bahan}

Bahan yang digunakan dalam pembentukan populasi sintetis adalah lima strain ikan mas founder, terdiri atas strain Majalaya, Rajadanu, Wildan, Sutisna, dan Sinyonya. Jumlah induk yang disiapkan masing-masing strain sebanyak enam pasang dengan bobot badan induk betina berkisar antara 1.200-2.500 g/ekor, sedangkan bobot badan induk jantan berkisar antara 600-1.500 g/ekor. Induk dari masing-masing strain diberi tanda (tag) dengan microchip dan dipelihara secara komunal, terpisah antara jantan dan betina. Selama masa pematangan gonad, induk diberi pakan buatan komersial khusus induk dengan kandungan protein 36\%38\% Pakan diberikan sebanyak 2\% dari bobot badan per hari dan diberikan dua kali sehari, setiap pagi dan sore. Pengamatan tingkat kematangan gonad (TKG) dilakukan setiap minggu dengan melihat penampilan fenotipik masing-masing induk. Induk dengan TKG-III-IV dipisahkan untuk dilakukan pemijahan. Jumlah induk yang dipijahkan sebanyak tiga pasang dari masing-masing strain.

\section{Pembentukan Populasi Sintetis}

Pembentukan populasi sintetis ikan mas dilakukan dengan menggabungkan semua strain founder ikan mas melalui pemijahan buatan. Pelaksanaan pemijahan buatan dibantu dengan Ovaprim ${ }^{\circledR}$ (kandungan hormon $\mathrm{sGnRHa} 20 \mu \mathrm{g} / \mathrm{mL}$ dan antidopamine $10 \mathrm{mg} / \mathrm{mL}$ ) dengan dosis $0,3 \mathrm{~mL} / \mathrm{kg}$ induk yang disuntikkan pada bagian belakang sirip punggung induk betina. Setelah delapan jam pascasuntik, dilakukan pengalinan (stripping) semua induk betina dan jantan dari masingmasing strain. Sebanyak $50 \mathrm{~g}$ telur dari masing-masing induk betina dari semua strain diambil dan dicampur (blended) menjadi satu dalam wadah fertilisasi. Sebanyak $5 \mathrm{~mL}$ sperma dari masing-masing induk jantan dari semua strain juga dicampur menjadi satu wadah. Selanjutnya sperma diencerkan sebesar 50 kali, yaitu dengan mencampurkan larutan fisiologis $\mathrm{NaCl}$ $0,9 \%$ Telur dalam wadah fertilisasi dibuahi dengan sperma dengan cara dicampur dan diaduk secara perlahan menggunakan bulu ayam yang sudah dibersihkan.

Telur-telur yang sudah difertilisasi disebar merata pada kakaban yang sudah ditempatkan di dalam bak penetasan dan pemeliharaan larva. Telur diinkubasi selama 2-3 hari hingga semua menetas dan kakaban segera diambil secara hati-hati agar larva yang masih menempel tidak ikut terbawa. Mulai hari keempat setelah menetas, larva diberi pakan nauplii Artemia secara ad-libitum, dan mulai hari ketujuh, larva diberi pakan komersial berbentuk tepung dengan kandungan protein 38\%40\%secara satiasi.

Pada umur dua minggu setelah menetas, benih dipindahkan ke kolam pendederan dengan kepadatan $25 \mathrm{ekor} / \mathrm{m}^{2}$. Selama 40 hari di dalam tahap pendederan, benih diberi pakan komersial berbentuk remah dengan kandungan protein $38 \% 40 \%$ secara satiasi. Benih hasil pendederan tersebut selanjutnya disebut populasi sintetis dan digunakan sebagai benih uji pada kegiatan evaluasi performa genotipik maupun fenotipik.

Secara bersamaan, sebanyak $10 \mathrm{~g}$ telur yang diperoleh dari proses pengalinan masing-masing strain 
ikan mas difertilisasi dengan sperma dari strain yang sama. Penanganan larva hingga tahap pendederan kelima strain ikan mas dilakukan dengan metode yang setara dengan penanganan benih populasi sintetis. Lima strain founder yang dipelihara secara terpisah tersebut digunakan sebagai populasi pembanding pada evaluasi performa genotipik dan fenotipik populasi sintetis.

\section{Evaluasi Performa Genotipik}

Ikan uji adalah benih populasi sintetis dan lima strain pembentuknya yang diambil secara acak dari kolam pendederan. Jumlah ikan uji pada evaluasi performa genotipik sebanyak 50 ekor per populasi dengan ukuran 10-12 g/ekor. Performa genotipik dianalisis menggunakan metode mikrosatelit DNA. Secara umum, metode ini terdiri atas empat tahapan, yaitu ekstraksi DNA, amplifikasi DNA dalam mesin PCR, elektroforesis, dan analisis fragmen DNA.

Ekstraksi DNA dilakukan dengan menggunakan kit komersial GeneJET DNA Purification Kit (Thermo Scientific, Lithuania), dengan prosedur mengikuti protokol yang terdapat pada manual kit. Sebanyak 2 í DNA genom hasil ekstraksi diamplifikasi dengan menggunakan type-it microsatellite PCR (Qiagen). Proses PCR dilakukan dengan program sebagai berikut: $95^{\circ} \mathrm{C}$ selama lima menit; $95^{\circ} \mathrm{C}$ selama 30 detik, $50^{\circ} \mathrm{C}$ $62^{\circ} \mathrm{C}$ selama 90 detik sesuai dengan suhu penempelan tiap primer, $72^{\circ} \mathrm{C}$ selama 30 detik, sebanyak 30 siklus; dan $60^{\circ} \mathrm{C}$ selama 30 menit.

Primer yang digunakan dalam analisis ini sebanyak lima jenis, yaitu MFW6, MFW7, MFW 9, MFW13, dan MFW16, mengikuti Syahputra et al. (2016). Hasil amplifikasi PCR diseparasi dengan metode elektroforesis pada gel agarose $2 \%$ yang telah diberi pewarna GelRedTM (Biotium). Hasil elektroforesis diamati di bawah lampu UV transilluminator dan difoto menggunakan kamera digital Canon EOS 1100D.

Polimorfisme lokus mikrosatelit ditapis dengan menggunakan alat analisis fragmen QIAxcel (Qiagen) dengan kit QIAxcel DNA screening (Qiagen). Ukuran alel ditentukan berdasarkan ukuran produk PCR relatif terhadap ukuran fragmen DNA pada QX size marker 50-800 bp (Qiagen). Data pola pita dan elektroforegram dianalisis menggunakan software QIAxcel Biocalculator (Qiagen) untuk memberi skor terhadap alel-alel yang muncul. Parameter keragaman genetik meliputi jumlah alel, frekuensi alel, diversitas gen, heterozigositas, polimorfisme, dan indeks fiksasi dianalisis menggunakan software PowerMaker V3.25.

\section{Evaluasi Performa Fenotipik}

Ikan uji adalah benih populasi sintetis dan lima strain pembentuknya yang diambil secara acak dari kolam pendederan. Jumlah ikan uji sebanyak 500 ekor per populasi dengan ukuran 10-12 g/ekor. Rancangan percobaan menggunakan rancangan acak lengkap dengan enam perlakuan berupa genotipe ikan mas, yaitu populasi sintetis dan lima strain ikan mas pembentuknya. Pengujian dilakukan di karamba jaring ukuran $3 \mathrm{~m} \times 5 \mathrm{~m}$ dengan kedalaman air berkisar antara 60-80 cm. Kepadatan benih saat ditebar sebanyak 10 ekor $/ \mathrm{m}^{2}$. Percobaan dilakukan dengan tiga kali pengulangan.

Selama 90 hari masa pemeliharaan, benih ikan diberi pakan komersial berbentuk pelet dengan kandungan protein 28\%31\% sebanyak $5 \%$ dari biomassa ikan per hari. Pakan diberikan dua kali sehari, pada saat pagi dan sore hari. Selama masa pemeliharaan, dilakukan evaluasi kualitas air media pemeliharaan benih meliputi: suhu, oksigen terlarut, $\mathrm{pH}$, amonia, dan nitrit. Evaluasi dilakukan setiap dua minggu sekali menggunakan alat quality water checker.

Pada akhir pemeliharaan, semua ikan dipanen dan dilakukan pengambilan contoh dari masing-masing karamba jaring sebanyak 30 ekor untuk pengukuran panjang standar dan penimbangan bobot badan. Selain itu, juga dilakukan penghitungan jumlah benih yang hidup untuk analisis tingkat sintasan dari masingmasing ulangan. Analisis biomassa saat panen dilakukan dengan mengalikan nilai sintasan dengan jumlah penebaran awal, serta dikalikan dengan bobot badan rata-rata pada saat panen. Data kualitas air media pemeliharaan ikan mas disajikan secara deskriptif.

\section{HASIL DAN BAHASAN}

\section{Karakter Genotipik}

Karakter genotipik meliputi jumlah alel setiap lokus, frekuensi alel, diversitas gen, heterozigositas, polimorfisme, dan indeks fiksasi po pulasi sintetis ikan mas disajikan pada Tabel 1. Hasil analisis mikrosatelit pada populasi sintetis menunjukkan adanya peningkatan nilai keragaman genetik yang signifikan dibandingkan lima strain founder pembentuknya. Beberapa parameter yang menunjukkan peningkatan keragaman genetik secara signifikan antara lain jumlah alel per lokus, heterozigositas, dan keseimbangan $\mathrm{He} /$ Ho.

Populasi sintetis mempunyai keragaman genetik khususnya pada parameter heterozigositas $(\mathrm{Ho})$ ratarata sebesar 0,31 . Nilai ini meningkat 55,0\% hingga $287,5 \%$ dibanding nilai heterozigositas $(\mathrm{Ho}$ ) rata-rata populasi founder, yang berkisar antara 0,08 hingga 0,20 . Satriani et al. (2011) menjelaskan bahwa keragaman genetik populasi berkorelasi positif dengan potensi kebugaran populasi (potential fitness). Semakin tinggi keragaman genetik populasi, maka 
Tabel 1. Nilai-nilai parameter genotipik populasi sintetis ikan mas dibandingkan populasi pembentuknya (founder)

Table 1. Genotypic parameters values of common carp synthetic populations compared to their founder populations

\begin{tabular}{lcccccc}
\hline \multirow{2}{*}{$\begin{array}{c}\text { Parameter } \\
\text { Parameters }\end{array}$} & $\begin{array}{c}\text { Populasi sintetis } \\
\text { Shyntetic population }\end{array}$ & Rajadanu & Sutisna & Majalaya & Wildan & Sinyonya \\
\hline Jumlah alel (Allele number) & 17,40 & 6,00 & 8,40 & 5,80 & 8,80 & 6,60 \\
Frekuensi alel (Allele frequency) & 0,19 & 0,33 & 0,23 & 0,36 & 0,22 & 0,33 \\
Heterozigositas (Heterozygosity) (Ho) & 0,31 & 0,10 & 0,08 & 0,14 & 0,20 & 0,10 \\
Diversitas gen (Gene diversity) (He) & 0,88 & 0,77 & 0,86 & 0,76 & 0,85 & 0,78 \\
Ho/He & 0,35 & 0,13 & 0,09 & 0,18 & 0,24 & 0,13 \\
Polimorfisme (Polymorphism) & 0,87 & 0,74 & 0,84 & 0,73 & 0,84 & 0,76 \\
Indeks fiksasi (Fixation index) & 0,65 & 0,88 & 0,92 & 0,84 & 0,79 & 0,89 \\
\hline
\end{tabular}

semakin besar peluang gen-gen aditif maupun dominan diwariskan melalui individu heterozigot dan terekspresi melalui fenotipe yang lebih baik. Peningkatan keragaman genetik dapat juga digunakan sebagai indikator pada seleksi sumber genetik (broodstock) generasi selanjutnya. Adanya peningkatan keragaman genetik pada populasi sintetis ini membuka peluang keberhasilan pelaksanaan program seleksi tersebut.

Nilai Ho/He populasi sintetis sebesar 0,35 mengindikasikan adanya defisit heterozigositas. Hal ini karena nilai heterozigositas teramati $(\mathrm{Ho})$ lebih kecil dari heterozigositas harapan ( $\mathrm{He}$ ) pada kondisi kesetimbangan Hardy-Weinberg. Namun demikian, nilai tersebut jauh lebih tinggi dibanding kelima populasi founder-nya. Hal ini menggambarkan bahwa populasi sintetis pada penelitian ini berada pada tingkat keseimbangan populasi yang lebih baik. Suatu populasi idealnya mempunyai keseimbangan populasi mendekati satu, dari generasi ke generasi berikutnya. Artinya, frekuensi alel dan gen dalam populasi tersebut bersifat konstan. Keseimbangan populasi tersebut dapat terganggu dengan adanya keadaan homozigot berlebihan (excess of homozygote) di dalam populasi. Munculnya homozigot berlebihan dapat disebabkan oleh fenomena null alleles, inbreeding, assortative mating, seleksi, dan kombinasi dari beberapa faktor tersebut (Syahputra et al., 2016).

Salah satu cara mempertahankan keseimbangan populasi adalah jumlah populasi yang besar, sehingga memungkinkan terjadinya perkawinan acak dengan tingkat fertilitas dan viabilitas yang sama tingginya (Hosseinnia et al., 2014). Lebih tingginya nilai keseimbangan $\mathrm{Ho} / \mathrm{He}$ populasi sintetis dibandingkan populasi pembentuknya diduga karena adanya fertilisasi yang bersifat acak antar lima strain founder ikan mas yang berbeda secara genotipe. Selain itu, jumlah total induk yang dipijahkan mencapai 30 ekor, jauh lebih banyak dibandingkan masing-masing populasi founder yang hanya enam ekor/strain.

Parameter lain yang cukup penting dalam mengevaluasi performa genotipik suatu populasi adalah nilai indeks fiksasi. Nilai ini menunjukkan status breeding populasi tersebut. Nilai indeks fiksasi populasi sintetis sebesar 0,65 lebih rendah dibanding populasi pembentuknya yang berkisar antara 0,79 hingga 0,92 . Nilai indeks fiksasi yang semakin kecil mengindikasikan bahwa status inbreeding populasi tersebut semakin rendah (Imron et al., 2011). Tingginya tingkat inbreeding kelima strain ikan mas pembentuk populasi sintetis ini sesuai dengan laporan Ariyanto et al. (2019a), yang menyatakan bahwa tingkat inbreeding ikan mas budidaya di Indonesia sudah sangat tinggi, sehingga perlu segera dilakukan perbaikan genetik.

Sebagaimana disampaikan oleh Tave (1993) bahwa populasi dengan tingkat inbreeding tinggi umumnya mempunyai nilai keragaman genetik rendah. Hal ini berpengaruh terhadap penampilan fenotipik populasi tersebut antara lain penurunan laju pertumbuhan, ketahanan terhadap penyakit, dan daya toleransi terhadap perubahan lingkungan. Pembentukan populasi sintetis yang merupakan penggabungan potensi genetik dari lima strain ikan mas berhasil meningkatkan nilai keragaman genetik dan secara bersamaan menekan tingkat inbreeding populasi ikan mas. Peningkatan performa genotipik populasi sintetis ini diharapkan berpengaruh secara nyata terhadap penampilan fenotipik populasi tersebut. 
Tabel 2. Karakter fenotipik biometrik populasi sintetis ikan mas yang dipelihara di kolam tanah selama 90 hari dibandingkan populasi tetuanya

Table 2. Phenotypic characters of the common carp synthetic populations cultured in net-cages for 90 days, compared to the founder populations

\begin{tabular}{|c|c|c|c|c|c|c|}
\hline \multirow[b]{2}{*}{$\begin{array}{l}\text { Parameter } \\
\text { Patameters }\end{array}$} & \multicolumn{6}{|c|}{ Strain (Strains) } \\
\hline & $\begin{array}{c}\text { Populasi sintetis } \\
\text { Shyntetic } \\
\text { population }\end{array}$ & Rajadanu & Sutisna & Majalaya & Wildan & Sinyonya \\
\hline Panjang (Length) (mm) & $103.6 \pm 15.2$ & $94.6 \pm 14.5$ & $100.5 \pm 13.1$ & $101.1 \pm 15.6$ & $99.6 \pm 14.6$ & $85.9 \pm 13.0$ \\
\hline Bobot (Weight) (g) & $46.6 \pm 19.2$ & $28.8 \pm 16.4$ & $40.0 \pm 20.6$ & $37.6 \pm 19.2$ & $42.6 \pm 19.7$ & $29.3 \pm 14.0$ \\
\hline Sintasan (Survival rate) (\%) & $56.5 \pm 0.9$ & $54.6 \pm 4.6$ & $48.5 \pm 6.9$ & $45.5 \pm 1.8$ & $54.6 \pm 5.5$ & $74.6 \pm 5.5$ \\
\hline Biomassa (Biomass) (kg) & $3.9 \pm 0.5$ & $2.35 \pm 1.3$ & $3.01 \pm 0.5$ & $2.6 \pm 0.4$ & $3.3 \pm 1.2$ & $3.3 \pm 0.3$ \\
\hline
\end{tabular}

\section{Karakter Fenotipik}

Karakter fenotipik populasi sintetis yang dipelihara selama 90 hari di karamba jaring disajikan pada Tabel 2. Penampilan fenotipik populasi sintetis relatif lebih baik pada semua karakter dibandingkan dengan strain founder pembentuknya. Pada parameter sintasan, populasi sintetis lebih rendah dibandingkan dengan strain Sinyonya.

Tabel 2 menunjukkan bahwa pembentukan populasi sintetis secara statistik tidak signifikan meningkatkan performa fenotipik ikan mas $(P>0,05)$. Penampilan fenotipik merupakan hasil akhir dari pengaruh faktor genetik dan lingkungan. Pada lingkungan yang sama, perbedaan penampilan fenotipik diduga lebih disebabkan adanya perbedaan karakter genetik. Pada beberapa kasus, adanya interaksi antara faktor genetik dengan lingkungannya juga dapat berpengaruh terhadap penampilan fenotipik populasi (Tave, 1993). Pada penelitian ini, metode pemeliharaan semua populasi dilakukan secara bersamaan di tempat yang sama. Hal ini dapat diasumsikan bahwa kondisi lingkungan pemeliharaan semua populasi adalah sama (Tabel 3). Secara umum, kualitas air media pemeliharaan benih uji berada dalam kisaran yang sesuai untuk ikan air tawar.

Hasil penelitian yang dilakukan oleh $\mathrm{Fu}$ et al. (2015), Ariyanto et al. (2018b; 2019b) menunjukkan bahwa interaksi antara faktor genetik dan lingkungan pada pemeliharaan ikan mas relatif kecil. Berdasarkan analisis tersebut, penampilan fenotipik populasi sintetis pada penelitian ini diduga kuat disebabkan karena adanya perbedaan keragaan genotipik.

Meskipun penampilan fenotipik, populasi sintetis tidak berbeda nyata namun potensi genetis yang diperoleh sangat menjanjikan. Eksploitasi potensi genetis dapat dilakukan antara lain melalui kegiatan seleksi, mengingat tingkat keragaman genotipik yang tinggi pada populasi tersebut. Pada tahap berikutnya, hasil seleksi yang diperoleh perlu ditindaklanjuti dengan beberapa pengujian terkait lingkungan

Tabel 3. Kualitas air media pemeliharaan populasi sintetis dan lima strain founder pembentuknya selama 90 hari

Table 3. Water quality variation in the cultured media of the synthetic and five strains founder population measured for 90 days

\begin{tabular}{lcc}
\hline \multicolumn{1}{c}{ Parameter (Patameters) } & Nilai (Nalues) & $\begin{array}{c}\text { Rekomendasi budidaya* } \\
\text { Aquaculture recommendation }\end{array}$ \\
\hline Suhu (Temperature) $\left({ }^{\circ} \mathrm{C}\right)$ & $28.0-31.2$ & $25.0-30.0$ \\
Oksigen terlarut (Dissolved oxygen) $(\mathrm{mg} / \mathrm{L})$ & $0.6-5.2$ & $>5.0$ \\
$\mathrm{pH}$ & $6.5-7.5$ & $6.5-8.5$ \\
Nitrit (Nitrite) $(\mathrm{mg} / \mathrm{L})$ & $0-0.05$ & $<1$ \\
Amonia (Ammonia) $(\mathrm{mg} / \mathrm{L})$ & $0-0.07$ & $<0.06$ \\
\hline
\end{tabular}

Sumber (Source): * BBPBAT, Sukabumi 
budidaya, seperti pengujian secara multilokasi dan multisistem. Hasil pengujian tersebut akan memberikan gambaran yang lebih utuh terkait penampilan fenotipik populasi sintetis ikan mas di lingkungan budidaya di Indonesia yang bervariasi.

\section{KESIMPULAN DAN SARAN}

Pembentukan populasi sintetis menggunakan lima strain ikan mas sebagai populasi founder tidak secara langsung meningkatkan performa benih ikan mas di lingkungan budidaya. Namun demikian, pembentukan populasi sintetis tersebut berhasil meningkatkan kualitas genetik populasi ikan mas, antara lain peningkatan keragaman genetik, serta penurunan tingkat inbreeding populasi. Peningkatan kualitas genetik populasi sintetis ini membuka peluang dilakukannya perbaikan kualitas benih ikan mas untuk kegiatan budidaya di masa mendatang, antara lain melalui kegiatan seleksi.

\section{UCAPAN TERIMA KASIH}

Penelitian ini dibiayai oleh APBN melalui DIPA pada Balai Riset Pemuliaan Ikan (BRPI) tahun 2017. Terima kasih disampaikan kepada semua penulis atas kontribusi masing-masing. Terima kasih juga disampaikan kepada semua teknisi lapangan dan laboran di BRPI.

\section{DAFTAR ACUAN}

Ariyanto, D., Carman, O., Soelistyowati, D.S.., Zairin, Jr.M., \& Syukur, M. (2018a). Karakteristik fenotipe dan genotipe lima strain ikan mas di Jawa Barat dan Banten. Jurnal Riset Akuakultur, 13(2), 93-103.

Ariyanto, D., Suharyanto, Palimirmo, F.S., \& Himawan, Y. (2018b). Pengaruh genotipe, lingkungan, dan interaksi keduanya terhadap stabilitas penampilan fenotipik ikan mas. Jurnal Riset Akuakultur, 13(4), 289-296.

Ariyanto, D., Himawan, Y., Palimirmo, F.S., \& Suharyanto. (2019a). Evaluasi tingkat inbreeding benih pada lima strain ikan mas (Cyprinus carpio). Prosiding Seminar Nasional Tahunan XVI Hasil Penelitian Perikanan dan Kelautan Tahun 2019. Universitas Gadjah Mada. Yogyakarta, 6 Juli 2019. hlm. 23-27.

Ariyanto, D., Himawan, Y., Syahputra, K., Palimirmo, F.S., \& Suharyanto. (2019b). Performa pertumbuhan dan produktivitas ikan mas strain Mustika pada uji multi lokasi. Jurnal Riset Akuakultur, 14(3), 139-144.

Fjalestad, K.T. (2005). Breeding strategies. In Gjedrem, T. (Ed.). Selection and Breeding Program in Aquaculture. Springer, Netherlands. p. 145-158.
Fu, J., Shen, Y., Xu, X., Liu, Ch., \& Li, J. (2015). Genetic parameter estimates and genotype by environment interaction analyses for early growth traits in grass carp (Ctenopharyngodon idella). Aquaculture International, 23, 1427-1441.

Gjedrem, T. \& Robinson, N. (2014). Advances by selective breeding for aquatic species: A review. Agricultural Sciences, 5, 1152-1158.

Hosseinnia, Z., Shabany, A., \& Kolangi-Miandare, H. (2014) Comparison of genetic variation of wild and farmed Bream (Abramis brama orientalis; berg, 1905) using microsatellite markers. Molecular Biology Research Communications, 3(3), 187-195.

Imron, Sunandar, D., \& Tahapari, E. (2011). Microsatellite genetic variation in cultured populations of African catfish (Clarias gariepinus) in Indonesia. Indonesian Aquaculture Journal, 6(1), 1-10.

Ninh, Ng.H., Thoa, Ng.Ph., Knibb, W., \& Nguyen, Ng.H. (2014). Selection for enhanced growth performance of nile tilapia (Oreochromis niloticus) in brackish water $\left(15^{\circ}-20^{\circ} \mathrm{ppt}\right)$ in Vietnam. Aquaculture, 428-429, 1-6.

Ødegård, J., Moen, Th., Santi, N., Korsvoll, SA., Kjøglum, S., \& Meuwissen, Th.H.E. (2014). Genomic prediction in an admixed population of Atlantic salmon (Salmo salar). Frontiers in Genetics, 5, 1-8.

Satriani, G.I., Soelistyowati, D.T., Hardianto, D., \& Aliah, R.S. (2011). Keragaman genetik ikan nila Oreochromis niloticus generasi kelima menggunakan marka DNA mikrosatelit. Jurnal Akuakultur Indonesia, 10(2), 124-130.

Sutthakiet, O., Koonawootrittriron, S., Chatchaiphan, S., Thaithungchin, Ch., \& Na-Nakorn, U. (2019). Genetic parameters of a snakeskin gourami (Trichopodus pectoralis, Regan 1910) base population created from crossing three hatchery stocks. Aquaculture, 512, 734358.

Syahputra, K., Ariyanto, D., \& Hayuningtyas, E.P. (2016). Keragaman genetik ikan mas (Cyprinus carpio) varietas Rajadanu tahan koi herpesvirus generasi F-0 dan F-1 menggunakan tiga lokus mikrosatelit. Jurnal Riset Akuakultur, 11(1), 59-66.

Tave, D. (1993). Genetic for fish hatchery managers. $2^{\text {nd }}$ ed. AVI. Connecticut: Publishing Company. Inc., $415 \mathrm{pp}$.

Xu, L.H., Wang, C.H., Jian, W., Dong, Z., Ma, Y.Q., \& Yang, $X$. (2012). Selection pressures have driven population differentiation of domesticated and wild common carp (Cyprinus carpio L.). Genetics and Molecular Research, 11(3), 3222-35. 